\title{
The Fraternity of Metaphors
}

\author{
By Des O'Rawe
}

Fall 2010 Issue of KINEMA

\section{THE FRATERNITY OF METAPHORS: JEAN-LUC GODARD'S FILM SOCIALISME}

The moment an artist takes notice of what other people want, and tries to supply the demand, he ceases to be an artist, and becomes a dull or amusing craftsman, an honest or dishonest tradesman.

Oscar Wilde, The Soul of Man Under Socialism ${ }^{(1)}$

JEAN LUC GODARD'S career in filmmaking began in the early 1950s when, as a young journalist (and lapsed anthropologist), he dabbled in some amateur and short documentary projects. His great breakthrough came with $\grave{A}$ bout de souffle (Breathless, 1960), and since then he has been directly involved in the production of over eighty films, many of which are major works of cinema. While there might seem to be discrete periods, or points of departure, in Godard's career (the heady days of the Nouvelle Vague, the Groupe Dziga Vertov phase, the mid-life 'autobiographical' turn, or, according to one publishing house: Les années Cahiers, Les années Karina, and Des années Mao aux années 80), there is also sufficient continuity of attitude and method to confuse the chapters that editors, critics, and biographers typically deploy to divide up that career. ${ }^{(2)}$ When viewing Godard's more recent work, however, it is difficult not to notice his time of life, or resist speculating on the affinities of thought and form in Film Socialisme (2010), and Notre musique (2005), Éloge de l'amour (In Praise of Love, 2001), and Voyage(s) en utopie (Voyage(s) in Utopia), his 2006 installation at the Centre Pompidou, of his own abandoned exhibition, Collage(s) de France. Is it now permissible to talk of a Godardian late style, and if so, is this a style shaped by an acceptance of the essential fragility of life and the necessity of death, or by a propensity for greater disruptiveness, playfulness - youthfulness, even?

Godard, himself, would be among the first to dismiss any talk of a discernible late style or eschatological phase, perhaps citing instead the coincidence of his current artistic collaborations (with ECM, for example ${ }^{(3)}$ ), the availability of new digital technologies, atrocities in Europe and elsewhere (especially, the Bosnian War), and other happenings unrelated to the question of his age. And yet, like everything he has made since Histoire(s) du cinéma (1988-1998) and reaching his sixties, Film Socialisme is mosaic-like in its forms and configurations, and markedly elegiac in its ruminations on history, cinema, art, and thought. While Godard's associative aesthetic and citational method - including his choice of 'actors', and the fragmentariness of his 'soundtracks' - can combine to create a remarkable cinematic event, the films themselves never cohere around a unifying concern, or yield to a thematic schema. Film Socialisme, then, does not offer us the illusion of narrative or structural integrity anymore than it contributes to the quotidian rhetoric of political and moral argument.

It is, however, a political film in the sense that it alters something more fundamental than opinions and points of view. It transforms a way of seeing and understanding reality and history, fiction and documentary, images, and images of images. If anything, it belongs to that dissident or 'dissensual' category of artwork capable of 'emancipating the spectator' by disturbing what Jacques Rancière terms 'the distribution of the sensible' in that it generates gaps, openings, and spaces, poses questions, invites associations but never posits a fixed position, imposes an interpretation, or allows itself to invest in the illusion of expressive objectivity and the stability of meaning. ${ }^{(4)}$ The myriad citations and fragments that comprise the film are never intended to culminate into anything cohesive, never mind conclusive. In one sense, they have no source and no context beyond their moment in the film itself, and what we make of that moment. It is the degree to which Godard allows these images and sounds to combine and collide, associate and dissolve that makes Film Socialisme a work of such endless provocation, and, therefore, an important work of cinema.

With an initial production budget of approximately $€ 300,000$, Film Socialisme took nearly four years to complete. It was premiered at the 2010 Cannes Film Festival, where Godard deftly infuriated reporters and cultural commentators by playing cat and mouse with the organisers, producing a two-minute trailer comprised of the entire film speeded-up, and offering subtitles in Navajo-English followed by ones that bore 
no necessary resemblance to the dialogue they were supposed to translate. The film, itself, was produced by Ruth Waldburger's Vega Film Company, Alain Sarde, and a consortium of European media groups, and cultural foundations. Wild Bunch, the film's Paris-based distributor, like Waldburger and Sarde, also played a major role in the production and distribution of Éloge de l'amour, Notre musique, and Anne-Marie Miéville's Après la reconciliation (Reaching Understanding, 2001), although both Waldburger and Sarde first became involved in producing films for Godard as far back as the early 1980s.

As with Histoire(s) du cinéma, Éloge de l'amour, and Four Short Films (2008) the release of Film Socialisme was accompanied by the publication of a book, a script of sorts comprised of statements, epigrams, and quotations. ${ }^{(5)}$ Film Socialisme: Dialogues avec visages auteurs provides images of authors' faces rather than names alongside its text, and the 'visages auteurs' belong to a predictably eclectic band of thirty-four famous writers, philosophers, and historic figures, all listed in the film credits under the heading, "TEXTOS". (6) As an appendix or envoi to the book, Godard has reproduced a long letter (with some parts visibly deleted) from the moral and political philosopher, Jean-Paul Curnier, who is also credited as one the writers of Film Socialisme, and who performs as himself in Notre musique (where he utters, amongst other things, the memorable statement: "moi je ne crois que dans les histories ou les témoins se font égorger" ["I only believe in stories in which the witnesses get their throats cut"]. ${ }^{(7)}$

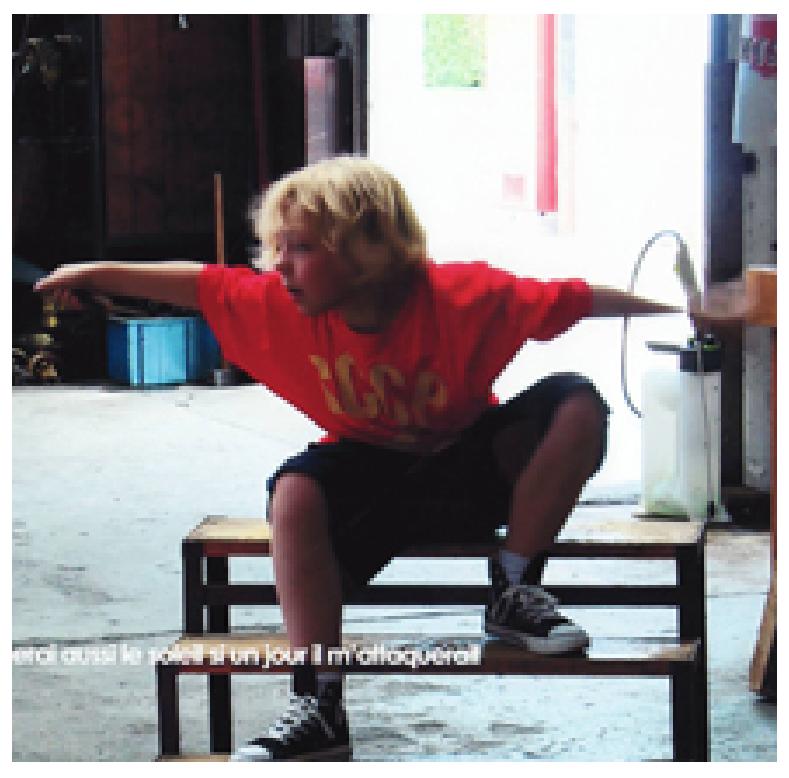

Figure 1: Film Socialisme by Jean-Luc Godard

The soundtrack to the film is comprised of fragments of music from a similarly diverse catalogue of composers and musicians, including "Néharot, Néharot" by the contemporary Israeli composer, Betty Olivero, (performed by the American-Armenian violinist, Kim Kashkasiah), the 1962 French version of Pete Seeger's "Where have All the Flowers Gone?" ("Que sont devenues les fleurs?") performed by the French-Egyptian diva, Dalida, the jazz fusions of Tunisian musician Anouar Brahem, the soft minimalism of Estonian composer, Avrö Part, and others, such as: Chet Baker, Madonna, Mozart and Beethoven. Many of the tracks although, 'traces' might be a better word - are explicitly influenced or fused by both Western and Eastern musical forms and genres, and the work of many of Godard's chosen composers and musicians is clearly shaped by painful migration histories. Similarly, the extracted shots and fragmented sequences from other films form a fragile palimpsest of divergent cultural, industrial, and historical forms. All Godard's films are in one way or another an 'histoire(s) du cinema', and Film Socialisme is no exception as each glimpse or montage of images gleaned from other films, other cinemas, appear and disappear, commenting upon, counterpointing, and at times even seeming to condemn the new world into which they have been reborn. As Rancière remarks: "With cinema images, Godard wants to do what cinema itself has not done, because it betrayed its vocation by sacrificing the fraternity of metaphors to the business of stories [...] By detaching metaphors from stories in order to fashion a different 'history' out of them, Godard fashions the cinema that 
has not existed."(8)

Many of the films cited in Film Socialisme are thematically political (and often East-West co-productions), for example: the experiences and attitudes of Israeli soldiers in Claude Lanzmann's Tsahal (1994); Dominique Chapuis and Patrick Baberis' 2001 homage to the Soviet filmmaker, Roman Karmen is another example; the French occupation of Egypt (1797-1803) as depicted in Youssef Chahine's Adieu Bonaparte (1985); Pasolini's Il fiore delle Mille e una notte (A Thousand and One Nights, 1974); Robert Rossen's 1956 Alexander the Great; Udi Aloni's controversial documentary on the Israeli-Palestine conflict, Local Angel (2002); the struggles of Tunisian Muslims and Sephardic Jews under Nazi occupation in Karin Albou's Chant des mariées (Wedding Song, 2008); Quattro giornate di Napoli (Four Days in Naples, Nanni Loy, 1963) which is based on accounts of the Neapolitan popular uprising against the Nazis in 1943; and André Malraux's autobiographical antiFascist Spanish Civil War film, Espoir (1945). Other films that appear seem to have a less explicitly political resonance: the digitally manipulated images of an elderly Michelangelo Antonioni studying Michelangelo's Moses from the silent short, Lo sguardo di Michelangelo (The Gaze of Michelangelo, 2004), for example, or the sequence featuring the trapeze artists from Agnès Varda's Les plages d'Agnès (The Beaches of Agnès, 2008), or the images from Jean-Daniel Pollet's (and Volker Schlöndorff's) Méditerranée (1963), a film that had influenced Godard during the production of Le mépris (Contempt, 1963) which itself, of course, is also present in Film Socialisme.

Arguably, the film's most intriguing credits are those of the actors who include: Catherine Tanvier (former French international tennis-player); Christian Sinniger (Swiss actor and noted theorist of improvisation techniques); Bernard Maris (neo-Keynesian economist, journalist, and environmentalist); Patti Smith (the New York singer-songwriter, and Francophile) and her guitarist, Lenny Kaye; Alain Badiou (Marxist philosopher, and writer); Elias Sanbar (Palestinian-born French intellectual, who has worked with Godard from time to time since Ici et ailleurs, and his visit to Palestine in 1970); Robert (Bob) Maloubier (former WW2 S.O.E. agent, spy, security consultant, and successful author, who worked in Africa throughout the post-war period for oil companies such as Elf and Shell); and the French-Senegalese actor, Nadége Beausson-Diagne, who is still chiefly associated with her role in Le Silence de la forêt/ The Forest (2003, Bassek Ba Kobhio and Didier Ouénangaré), a popular African-French feature production dealing with postcolonial racism, and environmental issues.

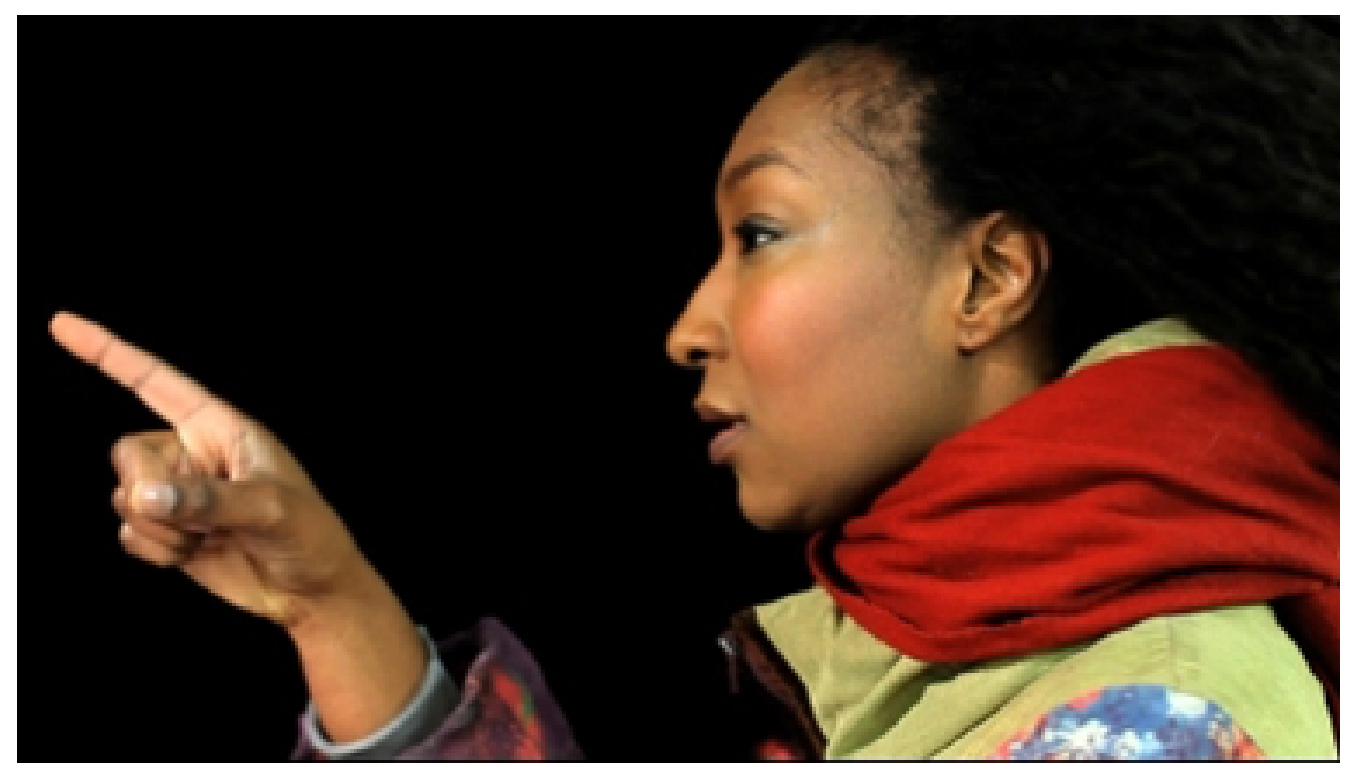

Figure 2: Film Socialisme

As with Notre musique, Film Socialisme adopts a triptych structure ("a film in three movements"): people and places on a Mediterranean cruise; aspects of European civilisation and history; and finally, a television news crew covering political events within a family somewhere in Switzerland (who run an Agrola garage). In 
Notre musique, the three-part structure was explicitly derived from Dante's Divine Comedy (Hell-PurgatoryParadise) whereas in this film it seems more arbitrary but may reflect the three major projects of French historian Fernand Braudel: the Mediterranean; Civilisation and Capitalism; and identity in contemporary France. ${ }^{(9)}$ The pre-credit opening image is what looks like video footage of two parrots on a branch. This image could be a (metaphorical) reference to language, mimicry, or the animals going into the ark (two-bytwo), or possibly it represents something to do with exoticism, exploration, treasure (island), or it might well be a cryptic reference to the parrot used by Metro Pictures as their logo before it merged in Goldwyn Picture Corporation in 1920, or even, the parrot in Pierrot le fou (1965). One thing is certain: even before the opening credit sequence has begun, Godard takes us into a world of endless allusive and associative possibilities, a world that demands an inventive, rather than a derivative or dutiful, critical response. Following this prelude, then, there is neither music nor silence, only the intermittent sync-plop as the title credits appear (emphatic red and white block lettering against a black background, reminiscent of La Chinoise (1967) under Greekstyle headings: "LOGOS [words by]", "TEKHNOS [technology by]", "TEXTOS [texts by]", "VIDEOS [films by]", and "AUDIOS [music by]", before finally, the film title itself. The inclusion of the sync-plop might signify nothing other than non-synchronicity, and the familiar modernist practice of foregrounding the given materials of the creative process. The heading and lettering of the opening credit sequence seems also to be a deliberate rejection of iconic conventions and the absurdity (and structural inequity) of the division of labour in virtually all commercial film and media industries. No first names, no category for actors - no glamorisation or idolisation of the individual, no stardom is countenanced in Film Socialisme.

These opening title sequences are followed by a medium close-up of the ocean, with the hum of an engine and some distant voices in the background. Then, a brief exchange between a man and a woman is heard off-screen: (M) "L'argent est un bien public" ["Money is a common good"] - (W) "Comme l'eau alors" ["Like water"] - (M) "Exactement" ["Exactly"]. The film then cuts to another close shot of the water, this time being churned by a movement of a ship's engines. The dialogue concludes: (M) "Alger la blanche ... Quand Mireille Balin laisse tomber Pépé le Moko ["White Algeria ... when Mireille Balin gives up on Pépé le Moko"]. A relationship between money and water, gold and drought, is enunciated both in the film's dialogue and its location. This is a luxury cruise liner, calling to mind (to my mind, at any rate) not only contemporary Western affluence and tourism but also films such as Fellini's E la nave va (And the Ship Sails On, 1984), or Leo McCary's Love Affair (1939) and its 1957 remake An Affair to Remember, or Gentlemen Prefer Blondes (1953, Howard Hawks), Ship of Fools (1965, Stanley Kramer), or even so-called 'disaster' movies such as The Poseidon Adventure (1972, Ronald Neame), and the gargantuan Hollywood money-spinner, Titanic (1997, James Cameron), a 'money and water' spectacle that reputedly cost $\$ 250 \mathrm{~m}$ to make (and has cost people a further $\$ 1.8 \mathrm{~b}$ to watch!). Godard, meanwhile, offers us a passing reference in his dialogue to Pépé le Moko (1937, Julien Duvivier), and an evocation of Pépé (Jean Gabin) fleeing the Casbah before the ship sails, lovesick for Gaby (Mireille Balin), homesick for Place Blanche, doomed. Even in these opening moments, the richness of Godard's associative aesthetic is evident, even if its logic is not: Algeria and Paris, Africa and Europe, corruption, colonisation, and the true love of a false man.

The next shot frames a character (Mathias Domahidy), side on and in medium close-up, standing on the deck of the ship. He is looking through the viewfinder of - and toying with - an SLR camera. Godard makes no attempt to reduce the noise of the wind which flaps and blusters across the soundtrack. There is the sound of some manic laughter in the background as the man continues looking out to sea, and then turns toward the camera. A woman's voice is heard: "Et nous ... Quand une fois de plus on a laissé tomber L'Afrique" ["And us, yet again, we have given up on Africa"]. The man points his camera out to sea, and looks, hesitates, turns. The film then cuts to a medium close-up of the woman (Beausson-Diagne), who seems to be standing beneath him (although, the point of view is ambiguous).

Another off-screen voice is heard over the noise of the wind (which itself might call to mind the title of another political film, Vent d'est (1969, Godard and Gorin), and the drone of the ship's engines: "Constance vous ne pouviez pas faire autre chose. On sait bien qu'en allant au Sud les degrés de Latitude deviennent négatifs il ne nous reste que le Nord chère âme, chère amie" ["Constance, there is nothing else you could have done. Everybody knows that when going to the South the Latitude becomes negative and all that remains is the North, precious soul, precious friend"]. The woman continues to lean against the deck railings; a boy's voice is now heard: "Il te reste la montre marraine" ["You still have the christening watch"]. The man again 
speaks: "Allez terminés les crimes et le sang Terminé Kigali ... Vivre les vacances!" ["Enough of crimes and bloodshed, enough of Kigali ... Long live holidays!"]. Although Film Socialisme is shot entirely on DV, it includes and refers to an array of filming technologies and viewing formats (e.g. cell-phone, camcorders, HD, CCTV, laptop screens, plasma screen television, etc.) and the broader aesthetic and political implications of this democratisation of image-making technologies naturally interests Godard. The man (Mathias) holds the SLR camera but seems hesitant, awkward in his gestures, un-choreographed like the soundtrack with its interruptions and intrusive natural noise. A little later his hands are filmed in still-motion close-up changing the SLR camera lens. The dialogue mentions Africa, and the consumerism, tourism, and voyeurism of Europe thereby seems juxtaposed with genocide and starvation in Rwanda, and the plight of the developing world, generally. The setting is (in both fact and fiction) a luxury cruiser, the Costa Serene, which in 2009 featured in a cable 'reality documentary' series, Cruise Ship Diaries.

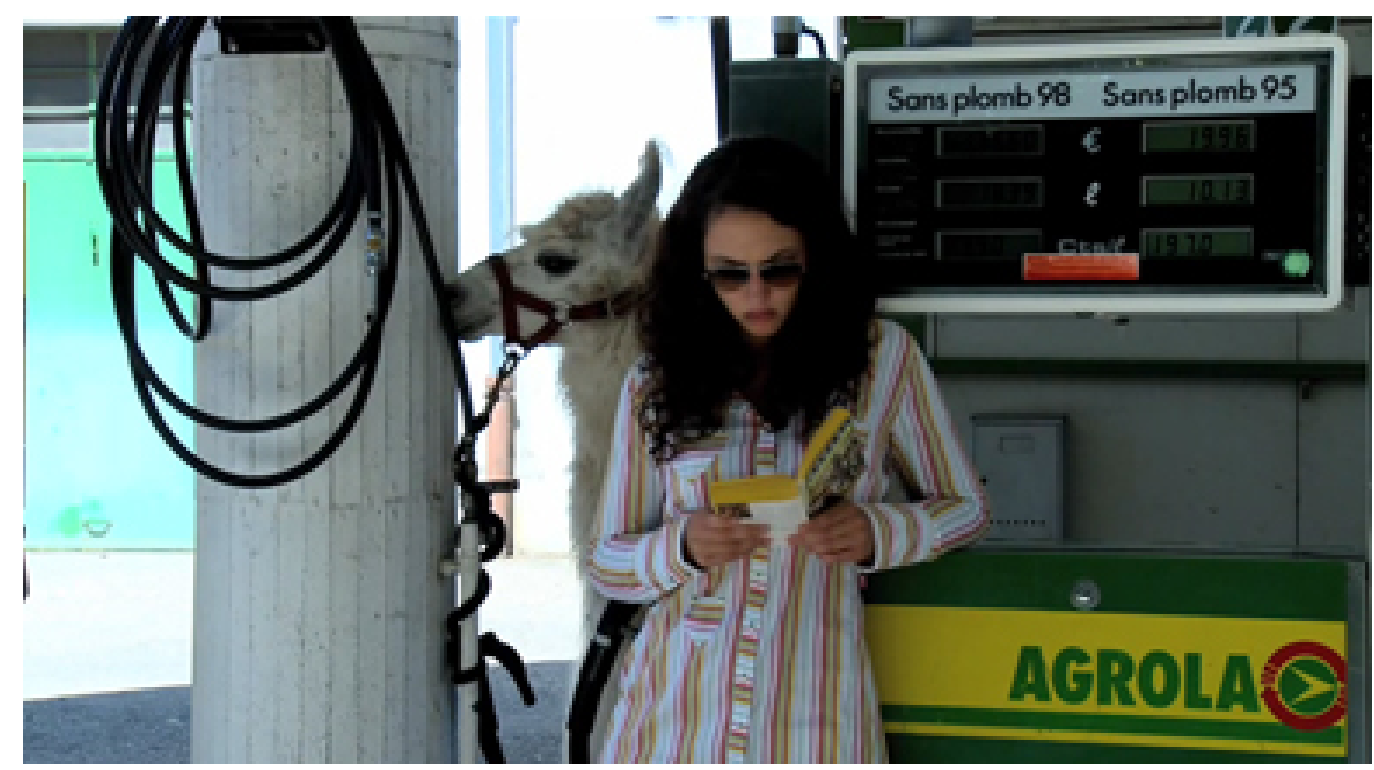

Figure 3: Film Socialisme

As this - the longest - section of the film develops, the cruise ship might inevitably seem to function as a kind of metaphor. Its colouring is digitally enhanced, its destinations are transformed into mythological places, and the passengers become oblique archetypes: an economist who plays slot-machines (one-armed bandits), a professor who lectures on geometry to an empty auditorium, a war criminal (Otto Goldberg) caught on CCTV, Russian secret agents, a troubadour strolling the ship's promenade, adult children and childish adults, and so forth. It is also a world of alienated souls, a 'ship of fools' that is at sea in every sense. Interestingly, the film also appears to evoke Marnie (Hitchcock, 1964), and not only Marnie's attempt to drown herself in a cruise ship's swimming pool during her honeymoon, but also the surreal establishing shot of the Baltimore street where she grew up, with a liner dominating the skyline, is itself here 'remade' by Godard. 'Fatale beauté' being what it is, the world of the ship cannot escape or elude culpability, and everywhere there are other reminders - prompts - that bring history on board: the cruel political economy of oil, the plight of Africa, the perpetual legacy of collaborators and war criminals (Bosnia, Kosovo, Sierra Leone, and the betrayals and interrogations at 84 Avenue Foch during WW2).

Similarly, in the second part of the film, the constitutional travails of the Martin family - even with its many ludic moments - can appear to revolve around a familiar set of oppositions, for example those between government (parents) and the governed (children), private (family) and public (media) communication, home (farm) and work (garage), creativity (music) and conformity (adding and auditing) ... a llama and a donkey. Godard keeps binary possibilities in play, and at no point does he allow a motivated plot to materialise, or facile ideological oppositions to take hold, certainly not ones that would resemble a (Hollywood) narrative where seeing is believing - literally. As Sam Rohdie comments in his recent essay on Historie(s) du cinéma: "Nothing for Godard stands still, least of all his own films. At best, the real can only be glimpsed, momen- 
tarily, in the in-between of perpetual arrangements, in its passage from and towards. It has no more fixity than the past has, and is always subject to the vagaries of the present."(10)

In this sense at least, Godard's approach to filmmaking continues to be influenced by his contempt for the 'fixed' world according to Hollywood Capitalism - as opposed to that of Film Socialism. This antagonism remains based on a core belief that in matters of cinema the form is the message and not the content, regardless of how appealing, entertaining, liberal or charitable that content may seem to be. HollywoodCapitalism has created a version of reality that saturates every aspect of life and visual culture, from 'Reality TV' to cable news and sports coverage, YouTube to Pixar movies: it is a version of reality that obscures reality. From a Godardian perspective, then, someone like Michael Moore, for example, is a performer rather than a filmmaker because his work so dutifully obeys the signature forms - the 'bad light' - of Hollywood-Capitalism. Moore is merely the self-made star of his own bad cinema, acting out the role of the heroic anti-hero who battles corruption and exploitation: he is the topic of his films, not General Motors, GlaxoSmithKline, or greedy bankers (as in his Capitalism: A Love Story (2009)). In truth, Michael's Moore's films are obedient in the worst sense, and when set alongside Godard's work, they are every bit as intellectually banal and irrelevant as Titanic, or The Poseidon Aventure(s).

In analysing Film Socialisme it is of course fascinating to excavate and connect with this or that association or potential metaphor, to delve into its trove of citations and quotations, images and epigrams, to fish for pearls, but even this 'archeological' activity is somewhat beside the point. This caveat is especially borne out in film's closing sequence, a complex montage developed around six key sites of what Godard terms, "Nos Humanités": Egypt, Palestine, Odessa, Greece, Naples, and Barcelona. The images and sounds are themselves archaeological in the sense that they both refer to actual sites and artefacts, films and documents, but what is more important is the way in which the sequence formally resembles archaeological practices (digging, sifting, dusting, assorting, exhibiting) through its extensive use of dissolve shots and superimposition techniques. In keeping everything in play, across the surface rather than into some illusory centre, Godard remains a custodian of both an alternative way of making film, and an alternative way of experiencing life. Unlike Joyce and Finnegans Wake, he does not claim to make art to keep the professors guessing. If he wants his cinema to illuminate, entertain, and inspire he also knows that the rhythm of its forms, patterns, and ambiguities, silences and interruptions - its attractions - work against the assumptions of conventional criticism. If Film Socialisme demands anything from those of us who want to articulate an appreciation or suggest an interpretation, it demands a quality of engagement intimately related to our own autobiography and filmography, our own histoire(s). Forever young, Godard's cinema continues to liberate the imagination by opposing the powerful, profitable world of 'consensual' cinema, and its myths of closure:

Q. A last film?

JLG. Nothing more than a title:" Farewell to Language".(11)

\section{Notes}

1. Oscar Wilde, "The Soul of Man Under Socialism," in The Soul of Man Under Socialism and Selected Critical Prose, ed. Linda Dowling (Harmondsworth: Penguin, 2001), 142.

2. Flammarion published these anthologies as a box-set by in 2007. On the question of a "later" Godard, see the essays anthologised in Michael Temple and James S. Williams, eds., The Cinema Alone: Essays on the Work of Jean-Luc Godard, 1985-2000 (Amsterdam: Amsterdam University Press, 2000), and Colin McCabe, Godard: A Portrait of the Artist at Seventy (New York: Farrar, Straus and Giroux, 2003), 320-333.

3. Editions of Contemporary Music (ECM) is an independent record company, founded by Manfred Eicher, in 1969. Originally formed to produce the work of contemporary composers and jazz musicians, with a particular emphasis on promoting improvisation and "transcultural experimentation," its interests (especially, since the 1980s) now include soundtrack production, and multi-media installation works. See, Jean-Luc Godard and Anne-Marie Miéville, "Our Music: Synopsis for a Film," in Horizons Touched: The Music of ECM, eds. Steve Lake and Paul Griffiths (London: Granta, 2007), 3-6.

4. Jacques Rancière, The Politics of Aesthetics, trans. Gabriel Rockhill (London: Continuum, 2004), 42-48. 


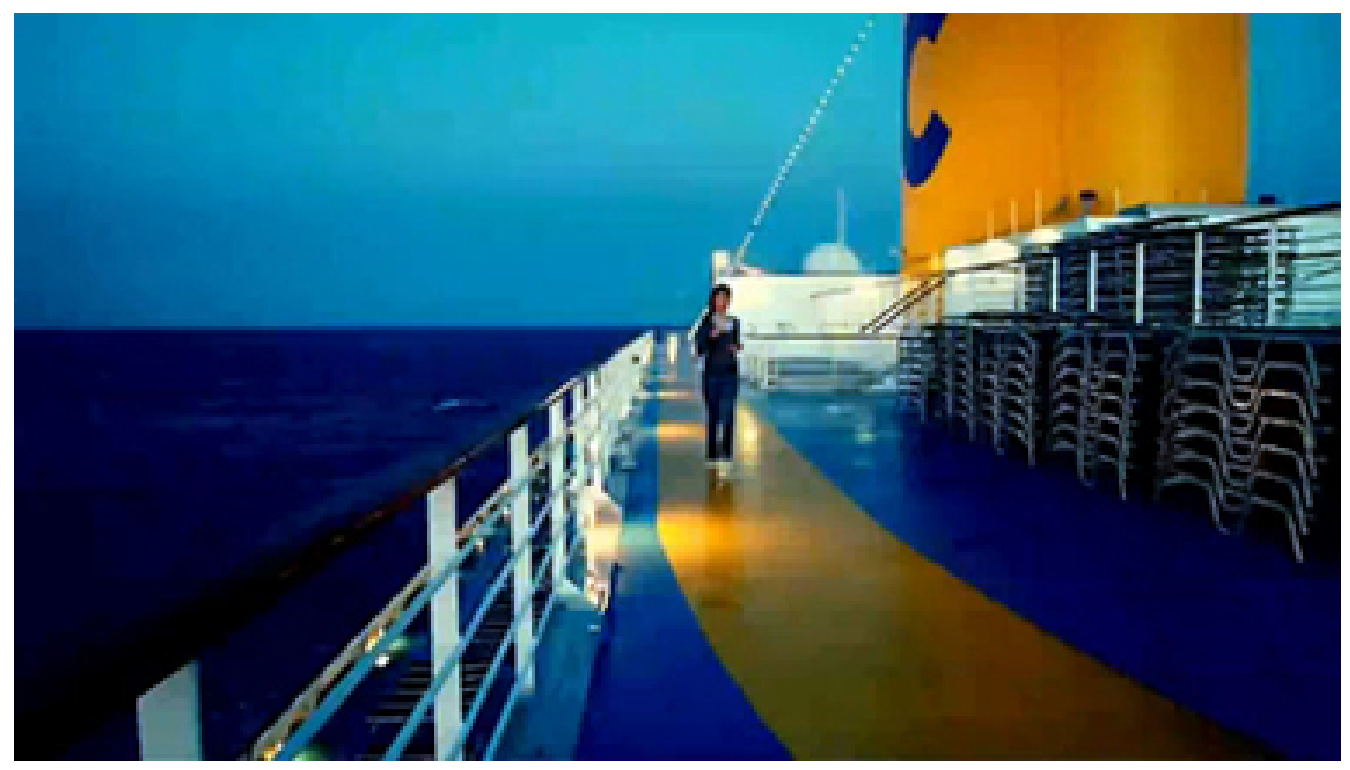

Figure 4: Film Socialisme

See also: Rancière, "The Paradoxes of Political Art," in Dissensus: On Politics and Aesthetics, ed. and trans. Steven Corcoran (London: Continuum, 2010), 134-151.

5. Jean-Luc Godard, Histoire(s) du cinéma (Paris: Gallimard, 1998); Eloge de l'amour (Paris: P.O.L., 2001); Four Short Films: L'Origine du XXIéme siècle; The Old Place; Liberté et Patrie; Je vous salue, Sarajevo (München: ECM, 2008). According to Brenez, L'Origine du XXIéme siècle is a first draft of Film Socialisme. See her "Liberté, fraternité, prodigalité," Cahiers du cinéma, 657 (2010): 26-27.

6. Jean-Luc Godard, Film Socialisme: Dialogues avec visages auteurs (Paris: P.O.L., 2010). The 'visages' in question are: Walter Benjamin, Jacques Derrida, Jean-Paul Curnier, Roland Dubillard, Hannah Arendt, Otto von Bismarck, Jean-Paul Sartre, Jacques Brunschwig, Jean Giraudoux, Jean Tadieu, Charles Peguy, Louis Aragon, Stéphane Rullac, Henri Bergson, Georges Bernanos, Denis de Rougement, Christa Wolff, Rimsky-Korsakov, Fernaud Braudel, Claude Simon, Neal Gabler, Luigi Pirandello, Paul Ricoeur, Samuel Beckett, André Malraux, Claude Lévi-Strauss, Joseph Conrad, William Shakespeare, Martin Heidegger, François de La Rochefoucauld, Goethe, Curzio Malaparte, Jean Genet, and Zoé Oldenbourg. Although mainly in French, the book - like the film - contains un-translated passages in other languages such as German, Russian, English, Chinese, Greek, and Arabic. Needless to say, in the book the author's image does not necessarily correspond to the "quotation" it accompanies.

7. Qtd. and trans. in Irmgard Emmelhainz's "Before Our Eyes: Les mots, non les choses: Jean-Luc Godard's Ici et Ailleurs (1970-74) and Notre musique (2004)," (PhD diss., University of Toronto, 2009), 327. Godard had originally decided on Socialisme as the film's title but on noticing in a correspondence with Curnier that the philosopher had misread "Vega Film [-] Socialisme" as "Vega [-] Film Socialisme," he changed it accordingly.

8. Jacques Rancière, The Emancipated Spectator, trans. Gregory Elliott (London: Verso, 2009), 130.

9. See, Peter Burke, The French Historical Revolution: Annales School, 1929-1989 (London: Polity, 1990), $32-64$.

10. Sam Rohdie, "Deux ou trois choses ...," Critical Quarterly, 51.3. 2009. 94.

11. Renaud Deflins, [Interview with Jean-Luc Godard] SUD Rail Magazine, 15 April, 2010: http://www.festivalcannes.com/assets/Image/Direct/033107.pdf Needless to say, the interview is fictional. See, Nicole Brenez's email to Craig Keller's Cinemasparagus blog regarding the historical significance of 'Renaud Deflins' (Usine 
Renault de Flins) and SUD Rail (Solitaires Unitaires Démocratique):

http://www.Cinemasparagus.blogspot.com/2010/05/film-Socialisme-press-book-interview.html

\section{References}

\section{Bibliography}

Brenez, Nicole. "Liberté, fraternité, prodigalité." Cahiers du cinema 657 (2010): 26-27.

et al., eds. Jean-Luc Godard: Documents. Paris: Centre Pompidou, 2006.

Burke, Peter. The French Historical Revolution: Annales School, 1929-1989. London: Polity, 1990.

Emmelhainz, Irmgard. "Before Our Eyes: Les mots, non les choses: Jean-Luc Godard's Ici et ailleurs (1970-74) and Notre musique (2004)." PhD diss., University of Toronto, 2009.

Godard, Jean-Luc. Histoire(s) du cinéma. Paris: Gallimard, 1998.

Éloge de l'amour. Paris: P.O.L., 2001.

and Youssef Ishaghpour. Cinema: The Archaeology of Film and the Memory of a Century.

Translated by John Howe. Oxford: Berg, 2005.

and Anne-Marie Miéville. "Our Music: Synopsis for a Film." In Horizons Touched: The Music of ECM, edited by Steve Lake and Paul Griffiths, 3-6. London: Granta, 2007.

Four Short Films: L'Origine du XXIéme Siécle; The Old Place; Liberté et Patrie; Je vous salue, Sarajevo. München: ECM, 2008 [book and DVD].

. Film Socialisme: Dialogues avec visages auteurs. Paris: P.O.L., 2010.

2010.

. "Interview with Renaud Delfins". SUD Rail Magazine, 15 April, 2010. Accessed 19 September,

http://www.festival-cannes.com/assets/Image/Direct/033107.pdf

McCabe, Colin. Godard: A Portrait of the Artist at Seventy. New York: Farrar, Straus and Giroux, 2003.

Rancière, Jacques. The Politics of Aesthetics. Translated by Gabriel Rockhill. London: Continuum, 2004.

. The Emancipated Spectator. Translated by Gregory Elliott. London: Verso, 2009.

Continuum, 2010.

Rohdie, Sam. "Deux ou trois choses ...." Critical Quarterly 51.3 (2009): 85-99.

Temple, Michael and James S. Williams, eds. The Cinema Alone: Essays on the Work of Jean-Luc Godard, 1985-2000. Amsterdam: Amsterdam University Press, 2000.

\section{Author Information}

Des O'RAWE teaches Film Studies at Queen's University, Belfast. His research and writing focuses on film aesthetics and relations between cinema and other arts. Recent essays have appeared in Literature/Film Quarterly, Screen, Film Studies, Quarterly Review of Film and Television, Screening the Past, and other journals. He currently co-edits the Manchester University Press 'Cinema Aesthetics' series, and he has written widely on contemporary Irish film and visual culture. 